\title{
High-resolution varve studies in Baldeggersee (Switzerland): Project overview and limnological background data
}

\author{
B. Wehrli ${ }^{1}$, A. F. Lotter ${ }^{2,3}$, T. Schaller ${ }^{1}$ and M. Sturm ${ }^{2}$
}

${ }^{1}$ Swiss Federal Institute for Environmental Science and Technology (EAWAG) and Swiss Federal Institute of Technology (ETH), Limnological Research Center, CH-6047 Kastanienbaum, Switzerland

2 Swiss Federal Institute for Environmental Science and Technology (EAWAG), CH-8600 Dübendorf, Switzerland

3 Universität Bern, Geobotanisches Institut, Altenbergrain 21, CH-3013 Bern, Switzerland

Key words: Annually laminated lake sediments, eutrophication, phosphorus, nitrogen, oxygen, alkalinity, meromixis.

\begin{abstract}
This introduction to a series of high-resolution varve studies in Baldeggersee provides both an overview of the different subprojects as well as background information on relevant limnologial trends. The project was based on a new method of in-situ freezing of unconsolidated surficial sediments in deep lakes. With this freeze-core technique a detailed, high-resolution stratigraphy of the varved sediments at the deepest point of Baldeggersee has been established for the period of 1885-1993. Annual and seasonal sediment samples were analyzed. Concentrations of redox active metals in sediments were calibrated as proxy indicators for the reconstruction of hypolimnetic oxygen conditions. Particle size analysis and varve measurements were used to discriminate between the influence of nutrients and climate on sediment formation and accumulation. Baldeggersee is an ideal system for calibrating indicators of deep-water oxygen concentrations because it underwent dramatic changes in nutrient loading and redox conditions during this century. The hypolimnion has been seasonally anoxic for the last 100 years and phosphorus content decreased by a factor of five in the last 20 years. Meromixis was observed between 1960 and 1980. Since 1983 the deep water has been artificially oxygenated. This well documented change in deep-water oxygen concentration represents a unique whole-lake experiment that can be used to analyze the geochemical response of the sediments.
\end{abstract}

\section{Introduction}

Annually laminated lake sediments (varves) are among those environmental archives with the highest possible temporal resolution. Varved sediments have been used extensively in recent years to reconstruct the environmental history in lakecatchment areas and to assess continental climate change since the last glaciation (Zolitschka, 1990; Lotter, 1991). The most recent laminated lake sediments offer the advantage that sediment records can be compared with instrumental time series of 
limnological and meteorological data, which are often available for the last century. Varves deposited within this period may thus allow a calibration of proxy data.

The high resolution varve studies in Baldeggersee were initiated as part of the Swiss National Research Program "Climate Change and Natural Hazards" (Wehrli et al., 1997). This interdisciplinary effort was designed to study, for the first time, the varved sediments of the last 100 years in a deep lowland lake with annual or even sesonal resolution. Sedimentologists, paleoecologists and geochemists collaborated in the analysis of the varved sequence.

This special issue of Aquatic Sciences covers several aspects of the project such as the freeze coring technique (Lotter et al., 1997a), the sediment stratigraphy and geochemistry (Lotter et al., 1997b), the evaluation of trace metals as redox indicators (Schaller et al., 1997a, b), and the separation of trophic and climatic signals (Lotter and Birks, 1997). In this introductory paper we present overviews of the high-resolution studies and of the available limnological information on Baldeggersee. Time series of the key parameters such as oxygen, alkalinity, nitrogen, and phosphorus are presented and discussed in the context of the varve studies.

\section{Goals}

In the top sediment of many deep prealpine lakes in Central Europe varved sections are well documented (Züllig, 1982). They usually cover the last 50-100 years and are the result of increased eutrophication. However, a special approach is required to obtain a reliable time scale and samples at yearly or even seasonal resolution from such unconsolidated, highly water-saturated sediments. Accurate high-resolution sampling is a prerequisite for a statistical comparison of sediment time-series with limnological and meteorological instrumental records. It was the first task of the project to develop a new in-situ freeze coring system that would allow accurate sampling and subsequent analysis of undisturbed sediments from a water depth of $66 \mathrm{~m}$ in Baldeggersee. Layout and functioning of the device are described in the second paper of this issue (Lotter et al., 1997a). This new technology allowed, for the first time, continuous sedimentological and geochemical analyses on single varves, or even single seasonal layers, from a deep lake. An accurate chronology and stratigraphy for the time interval 1885-1993 (Lotter et al., 1997b) could be assessed, which provided the basis for the analyses of different geochemical, isotopic and sedimentological parameters. The data analysis was designed to contribute to the two following main objectives of the project:

1) to evaluate new proxy indicators for wind-induced mixing of the lake and

2) to disentangle the influence of eutrophication, meteorology and hydrological changes on varve formation.

Oxygen conditions in the deep water of a lake are governed by biological respiration rates at the sediment-water interface and by wind-induced mixing during winter. If primary production is approximately constant, hypolimnetic redox conditions should reflect the intensity of mixing during winter. As a consequence, the accumulation of redox active metals in sediments could change, thereby revealing information about wind-induced mixing. 
The relationship between wind intensity and oxygen concentration in the deep water is well established (Livingstone and Imboden, 1993). Transition-metal concentrations in sediments have been widely used as proxy indicators for benthic oxygen conditions in marine environments (Emerson and Huested, 1991; Thomson et al., 1993). We have, therefore, investigated the relationship between metal concentrations in lacustrine sediments and different deep-water oxygen conditons. The accumulation of redox active metals such as Fe, Mn, V, Cr, Mo, As was studied using both a sediment mapping approach (Schaller and Wehrli, 1997; Schaller et al., 1997 a) and by high resolution analysis of varves (Schaller et al., 1997b).

In order to discriminate between meteorological, hydrological and biological effects on varve formation Lotter and Birks (1997) performed different multivariate statistical analyses on varve parameters. Geochemical proxies such as TOC, TON, $\mathrm{Ca}, \mathrm{Mg}$ and size disteribution of calcite crystals have been evaluated for their potential to hindcast trophic state (Lotter et al., 1997 b). A high-resolution sediment trap study is under way to quantify the effects of rain events on allochthonous particle input and to study the fine details of varve formation (Sturm and Friedl, pers. communication).

\section{The site}

Baldeggersee (463 m asl) was formed more than 15000 years ago after the retreat of the Reuss glacier at the end of the Würm glaciation (Handke, 1970; 1980). Figure 1 shows the location of Baldeggersee as well as the bathymetry of the lake and Table 1 lists characteristic hydrographical parameters. The lake has a maximum depth of $66 \mathrm{~m}$, a volume of $0.173 \mathrm{~km}^{3}$ and a surface area of $5.2 \mathrm{~km}^{2}$. The mean hydraulic residence time is 4.3 years. The $4.5 \mathrm{~km}$ long and $1.5 \mathrm{~km}$ wide basin stretches in south to north direction. Today, the catchment area is used intensively

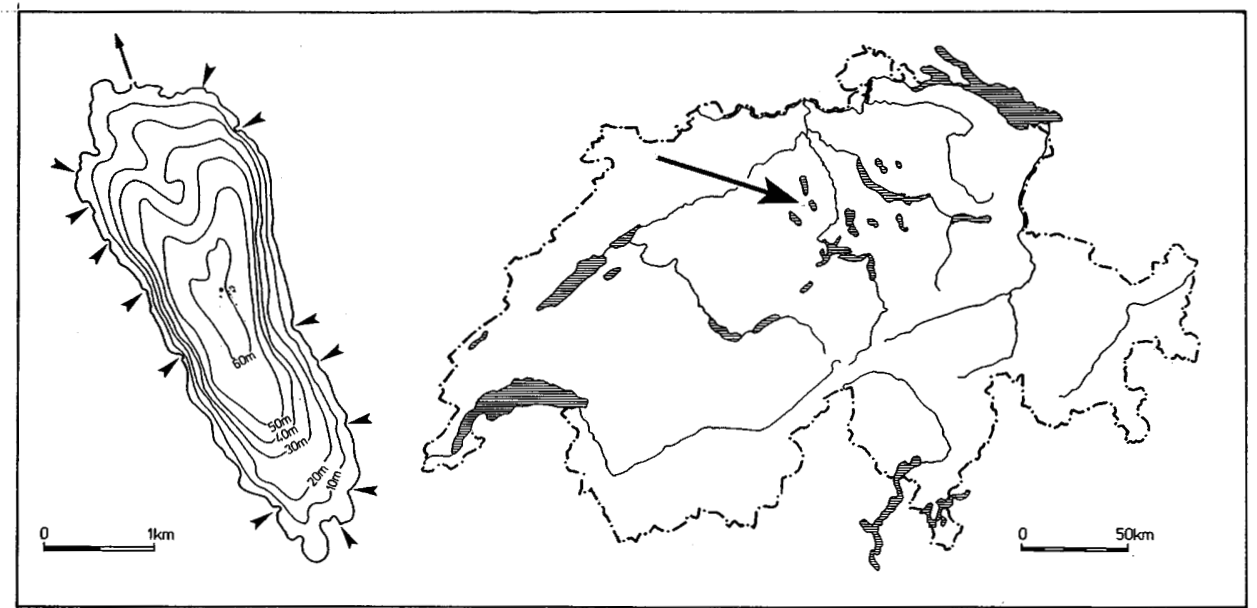

Figure 1. Location of Baldeggersee within Switzerland (arrow) and bathymetric map of the basin. Arrows indicate tributaries and outflow 
Table 1. Hydrographic lake parameters and bathymetry of Baldeggersee

\begin{tabular}{|c|c|c|}
\hline \multicolumn{3}{|c|}{ lake parameters } \\
\hline \multirow{7}{*}{\multicolumn{2}{|c|}{$\begin{array}{l}\text { lake surface } \\
\text { lake volume } \\
\text { average depth } \\
\text { maximum depth } \\
\text { mean hydraulic residence time } \\
\text { catchment area (without lake) } \\
\text { inhabitants in catchment (1990) }\end{array}$}} & $5.2 \mathrm{~km}^{2}$ \\
\hline & & $0.173 \mathrm{~km}^{3}$ \\
\hline & & $33 \mathrm{~m}$ \\
\hline & & $66 \mathrm{~m}$ \\
\hline & & 4.3 years \\
\hline & & $67.8 \mathrm{~km}^{2}$ \\
\hline & & 12243 \\
\hline \multicolumn{3}{|c|}{ bathymetry } \\
\hline depth & $\begin{array}{l}\text { volume below } \\
\text { depth }\left[\mathrm{km}^{3}\right]\end{array}$ & area $\left[\mathrm{km}^{2}\right]$ \\
\hline $0 \mathrm{~m}$ & 0.173 & 5.22 \\
\hline $10 \mathrm{~m}$ & 0.125 & 4.53 \\
\hline $20 \mathrm{~m}$ & 0.084 & 3.68 \\
\hline $30 \mathrm{~m}$ & 0.052 & 2.79 \\
\hline $40 \mathrm{~m}$ & 0.028 & 2.00 \\
\hline $50 \mathrm{~m}$ & 0.011 & 1.36 \\
\hline $60 \mathrm{~m}$ & 0.002 & 0.54 \\
\hline
\end{tabular}

for agriculture: $77 \%$ of the catchment area consists of agricultural land. Of the remaining area $12 \%$ is forested and $5 \%$ are covered by urban ares, roads etc.

Hill slopes of 700-800 m elevation asl on both sides shield the lake against the prevailing westerly winds. This setting facilitates oxygen depletion in the hypolimnion of Baldeggersee. Data from long piston cores show the occurrence of several varved sediment sections over the past 6000 years (M. Sturm, personal communication). This observation indicates that the hypolimnion of Baldeggersee experienced periods of anoxic conditions long before the onset of anthropogenically induced eutrophication.

The most recent varves at the deepest part of Baldeggersee cover the period of 1885 to present. This time window allows us to study the effects of eutrophication and changes in deep-water oxygen in great detail. The lake has been artifically oxygenated during summer and mixed with compressed air during since Winter 1982/83 (Stadelmann, 1984; Gächter, 1987; Wüest et al., 1992b). After several decades of meromixis and anoxia, this lake restoration program has successfully re-established oxic conditions in the hypolimnion (Stadelmann et al., 1993, 1997; Wehrli and Wüest, 1996). This artificial oxygenation represents a unique whole-lake experiment and provides the opportunity to study the effect of a sudden change in deepwater oxygen on geochemical parameters in the sediment.

\section{Sampling and analysis}

A sediment mapping based on 38 gravity cores was performed in autumn, 1992 (Schaller et al., 1997 a). The same gridpoints were sampled as in a previous study by 
Niessen and Sturm (1987). The goal was to provide two-dimensional information on the distribution of geochemical parameters such as POC, PON, phosphorus, and metals under different oxygen conditions (Schaller and Wehrli, 1997; Schaller et al., 1997 a). Three sediment levels were sampled in order to recover sediment deposited during the artificial oxygenation (after 1982/83), during the anoxic conditions in the deep water ( 1940-1980) and during the mesotrophic period (before 1885).

Three freeze cores from the deepest part of the basin were taken in autumn 1993 (Lotter et al., 1997b). An accurate stratigraphy and chronology could be established for the period 1885-1993. One core was sampled with annual resolution, the two others were used to obtain seasonal samples. The high-resolution analyses of the freeze cores included varve parameters such as layer thickness, water content and annual accumulation rates, major compounds such as POC, phosphorus, Ca etc. (Lotter et al., 1997b), stable isotopes (Teranes, 1997), diatoms (Lotter, 1997) and redox-active metals such as Fe, Mn, V, Cr, As, Mo (Schaller et al., 1997b).

The high-resolution varve sampling was accompanied by a sediment trap study at high temporal resolution. Daily samples of settling particles were sampled and analyzed during the time interval April 1994 to April 1996. The sediment traps provided further unequivocal evidence that the laminated sediments in Baldeggersee represent true varves, i.e. clearly discernible seasonal layers (Sturm and Friedl, pers. communication).

Finally, the diffusion of metals across the sediment-water interface was investigated by three deployments of dialysis porewater samplers. These data provided direct support for the postulated internal metal cycles in Baldeggersee (Schaller and Wehrli, 1997; Schaller et al., 1997a).

\section{Eutrophication and anoxia in Baldeggersee}

\section{Phosphorus and nitrogen}

The time series of average phosphorus and nitrogen concentrations in Baldeggersee are outlined in Figure 2. Mean concentrations have been calculated from concentration profiles measured during spring at the center of the lake and the bathymetric data (Table 1).

The monitoring program is a joint venture between the Kanton of Luzern and EAWAG. First measurements of phosphorus concentrations were made in 1952. The reported value of $0.08 \mathrm{~g}-\mathrm{P} \mathrm{m}^{-3}$ at that time shows that the lake had already made the transition from a mesotrophic to an eutrophic state in the first part of this century. After 1952 the P-concentrations increased almost exponentially, reaching an average of about $0.5 \mathrm{~g}-\mathrm{P} \mathrm{m}^{-3}$ in 1970 . Sewage diascharge, increased use of phosphate in detergents, and intensified fertilizer use in agriculture were responsible for this trend. A first sewage treatment plant was constructed in 1967. The upgrade, with additional chemical P-elimination, in 1980 reduced the P-input from domestic sources from $7.8 \mathrm{t}-\mathrm{P} \mathrm{yr}^{-1}$ (1958/59) to $2.2 \mathrm{t}-\mathrm{P} \mathrm{yr}^{-1}$ (1987/90) (Stadelmann et al., 1993). As a consequence, the P-content in the lake decreased after 1975. Over the last 20 years the average P-concentration diminished by a factor of 5 . The remaining phosphorus inputs of $14.6 \mathrm{t}-\mathrm{P} \mathrm{yr}^{-1}$ are dominated by runoff and washout from agricultural land (11.9 t-P yr ${ }^{-1}$ between 1987 and 1990; Stadelmann et al., 1993). 

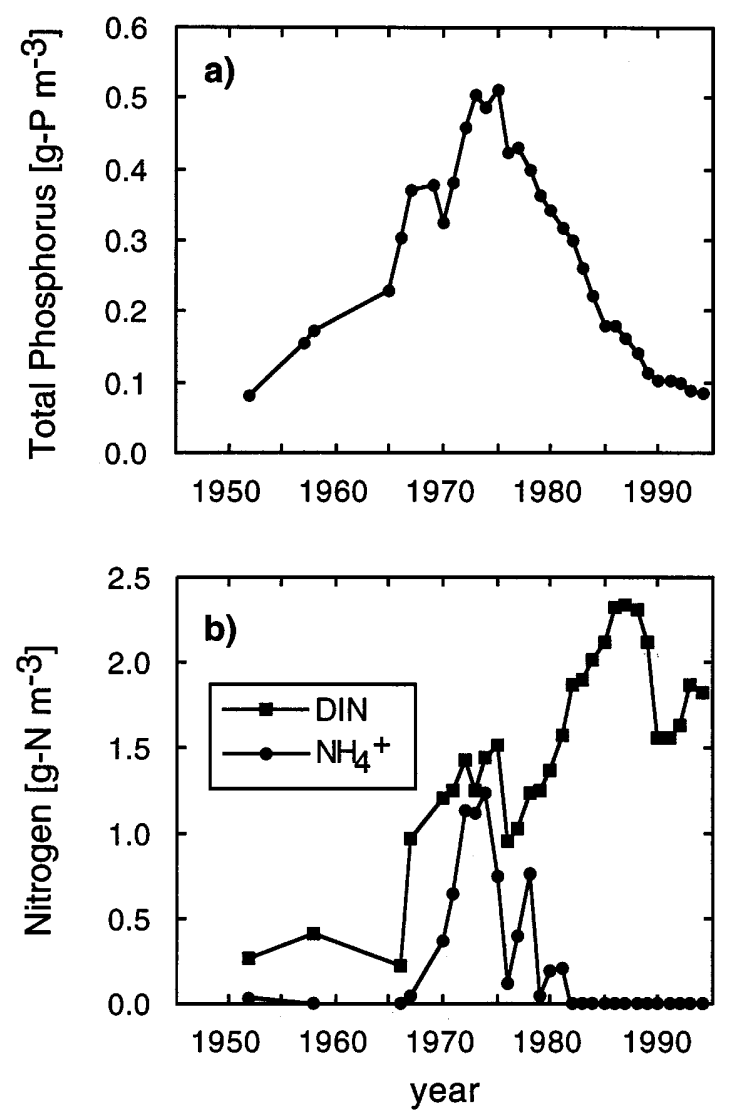

Figure 2. Time series of total phosphorus (a) and dissolved inorganic nitrogen $\left(\mathrm{NO}_{3}^{-}+\mathrm{NO}_{2}^{-}+\right.$ $\mathrm{NH}_{4}^{+}$) and ammonia (b) in Baldeggersee for the period of 1952-1994. The values were obtained from depth-averaged profiles taken during spring at the deepest point of the lake

Calculations using a one box model suggest that particulate phosphorus is readily deposited and that the dissolved fraction is responsible for eutrophication effects. Based on present day inputs, the calculations yielded steady-state concentration of $0.126 \pm 0.035 \mathrm{~g}-\mathrm{P} \mathrm{m}^{-3}$ (Wehrli and Wüest, 1996). In order to achieve a typical average concentration of $0.03 \mathrm{~g}-\mathrm{P} \mathrm{m}^{-3}$ for a mesotrophic lake, the inputs of dissolved phosphorus must be reduced from 8 to $3 \mathrm{t} \mathrm{P} \mathrm{yr}^{-1}$.

In contrast to phosphorus, nitrogen concentrations in the lake (Fig. 2b) have increased steadily. During the 1970s, a large fraction of dissolved inorganic nitrogen (DIN) was present as ammonia because meromictic conditions in the hypolimnion prevented nitrification during this period. After 1987 the DIN concentrations decreased slightly - a trend has been observed in many central Europe lakes. Mengis et al. (1997) attributed this nitrate decline during the late 1980s mostly to climatic conditions. In the case of Baldeggersee dry years with little runoff lead to a decrease in the nitrogen input from agricultural areas. 


\section{Oxygen and mixing}

In the early 1920 s varved sediments had already been observed in the deepest part of Baldeggersee (Nipkow, 1927), indicating seasonally anoxic conditions in the deep basin, which lasted sufficiently long (weeks to months) to prevent bioturbation by organisms such as tubificidae or chironomidae (e.g. Svensson and Leonardson, 1996). Using varve numbers as indicators for the onset anoxia in different water depths, and grain size of calcite crystals as indicator of phosphate concentration in the water column Niessen and Sturm (1987) reconstructed the history of anoxia in Baldeggersee for this century (Fig. 3). Around 1940 the anoxic part of the water column reached up to water depths of $40 \mathrm{~m}$, whereas between 1960 and 1980 extensive summer anoxia developed in the hypolimnion. During this period the lake showed clear evidence of meromixis, such as incomplete mixing of the deep water
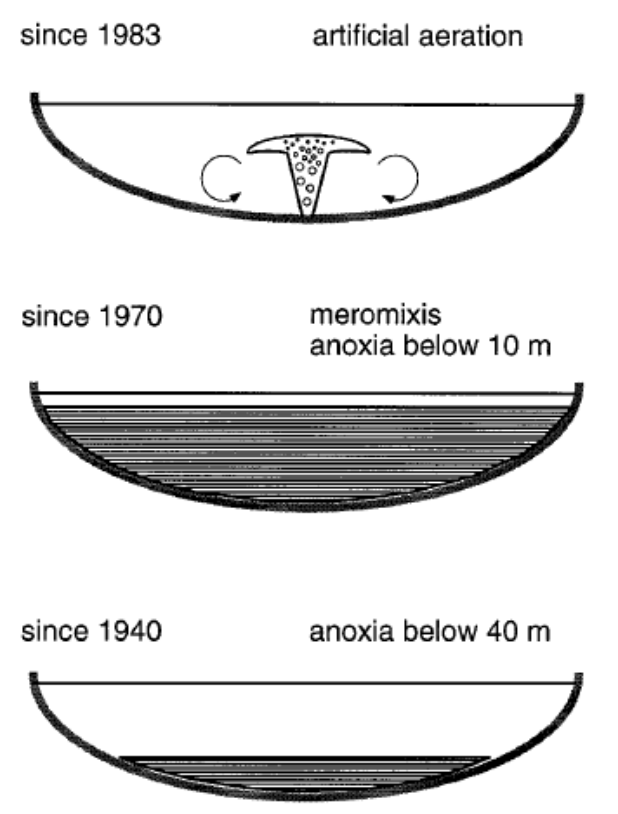

since $1885 \quad$ anoxia below $60 \mathrm{~m}$

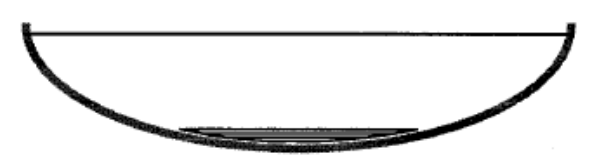

Figure 3. Schematic development of summer anoxia in the hypolimnion of Baldeggersee modified after Niessen and Sturm, 1987. The extent of hypolimnetic anoxia was estimated by varve counts. Since 1983 the hypolimnion is oxygenated during summer by a bubble plume of pure oxygen rising only to a depth of $20 \mathrm{~m}$ to keep the thermal stratification undisturbed. During winter a plume of compressed air induces full circulation of the water body 
during winter. Dissolution of a small fraction (a few \%) of the precipitated calcite in the hypolimnion is sufficient to stabilize the water column in a productive lake (Wüest et al., 1992a; Gruber et al., 1997). Moreover, incomplete mixing in one year can initiate a positive feedback - the longer the lake does not mix due to the absence of winter storms, the larger the density gradient in the deep water becomes.

Alkalinity is a good indicator for calcite dissolution and increased stability in the deep-water. It has been measured periodically since the 1950s. Figure 4 a shows that average hypolimnetic alkalinity (below $20 \mathrm{~m}$ water depth) has increased substantially in the $1950 \mathrm{~s}$. The time series indicates that deep water mixing was poor for more than 20 years (1958-1982). In 1982/83 the internal restoration, consisting of a bubble plume of pure oxyen during summer and injection of compressed air durinig winter, began. As a consequence of intense mixing and yearly overturn the hypolymnetic alkalinity is now below the levels of 1950 .
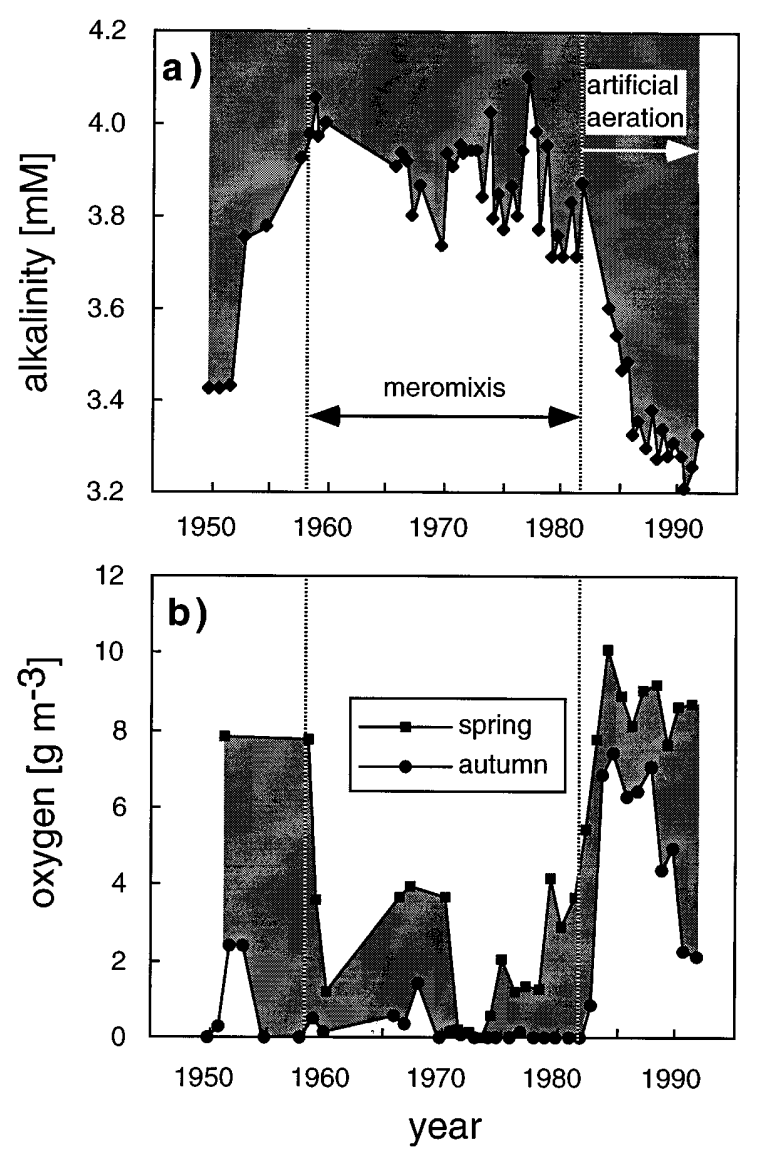

Figure 4. Time series of depth-averaged alkalinity and oxygen concentrations in the hypolimnion below $20 \mathrm{~m}$ water depth for the period of 1950-1993. The depth-averaged values were obtained from spring (alkalinity, $\left.\mathrm{O}_{2}\right)$ and autumn $\left(\mathrm{O}_{2}\right)$ concentration profiles at the deepest point of the lake 
Fluctuations in alkalinity are negatively correlated with the depth-averaged oxygen concentration in the water column below $20 \mathrm{~m}$. In Figure $4 \mathrm{~b}$ the difference between hypolimnetic oxygen concentrations in spring (March/April) and autumn (September/October) is emphasized. Mixing during winter produced spring values of about $8 \mathrm{~g}-\mathrm{O}_{2} \mathrm{~m}^{-3}$ during the 1950s. With the onset of meromixis in 1958 the depthaveraged oxygen concentrations below $20 \mathrm{~m}$ remained below $4 \mathrm{~g}-\mathrm{O}_{2} \mathrm{~m}^{-3}$ during the whole year. Extreme meromictic conditions were observed in the 1970 s, when the average oxygen concentration below $20 \mathrm{~m}$ was close to zero. The lake restoration after 1982/83 raised average oxygen concentrations during spring above $8 \mathrm{~g}-\mathrm{O}_{2} \mathrm{~m}^{-3}$, thus producing a dramatic and abrupt change in the redox conditions of the deep water (Fig. 4b).

The sediment studies in this issue of Aquatic Sciences will address the question, which kind of signals in the sediment can be attributed to the changes in redox conditions and trophic state of Baldeggersee.

\section{ACKNOWLEDGMENTS}

The varve studies in Baldeggersee were only possible thanks to the dedicated work in the field and in the laboratory of Alois Zwyssig, Caroline Stengel, Christian Dinkel, Erwin Grieder and Antonin Mares. The Environment Department of Kanton Luzern (Pius Stadelmann) and the "Gemeindeverband Baldegger- und Hallwilersee" provide access to their data and to the infrastructure on the lake. We thank Alfred Wüest and René Gächter for helpful discussions. This work was supported by the Swiss National Science Foundation through Research Program 31 (NFP-31) grant 4031-33147 and Priority Program Environment grant 5001-34876.

\section{REFERENCES}

Emerson, S. R. and S. S. Huesteed, 1991. Ocean anoxia and the concentrations of molybdenum and vanadium in seawater. Marine Chemistry 43:177-196.

Gächter, R., 1987. Lake restoration. Why oxgenation and artificial mixing cannot substitute for a decrease in the external phosphorus loading. Schweiz. Z. Hydrol. 49:170-185.

Gruber, N., B. Wehrli and A. Wüest, 1997. The role of biogeochemical cycling for the formation and preservation of varved sediments in Soppensee. Jouronal of Paleolimnology: in press.

Handke, R., 1970. Geschichte der Landschaft. In: Ur- und frühgeschichtliche Archäologie der Schweiz. Band 2. 5-16

Handke, R., 1980. Eiszeitalter 2. Die jüngste Erdgeschichte der Schweiz und ihrer Nachbargebiete. Letzte Warmzeiten, Würm-Eiszeit, Eisabbau, Nacheiszeit der Alpen-Nordseite vom Rheinzum Rhone-System. Ott Verlag, Thun, 703 pp.

Livingstone, D. M. and D. M. Imboden, 1993. The non-linear influence of wind-speed variability on gas transfer in lakes. Tellus $45 \mathrm{~B}: 275-295$.

Lotter, A. F., 1991. Absolute dating of late-glacial period in Switzerland using annually laminated sediments. Quaternary Research 35:321-330.

Lotter, A. F., 1997. The recent eutrophication of Baldeggersee (Switzerland) as assessed by fossil diatom assemblages. THE HOLOCENE: submitted.

Lotter, A. F. and H. J. B. Birks, 1997. The separation of the influence of nutrients and climate on the varve time-series of Baldeggersee, Switzerland. Aquatic Sciences 59:362-375.

Lotter, A. F., I. Renberg, H. Hansson, R. Stöckli and M. Sturm, 1997a. A remote controlled freeze corer for sampling unconsolidated surface sediments. Aquatic Sciences 59:295-303.

Lotter, A. F., M. Sturm, J. L. Teranes and B. Wehrli, 1997 b. Varve formation since 1985 and highresolution varve analyses in hypertrophic Baldeggersee (Switzerland). Aquatic Sciences 59: $304-325$. 
Mengis, M., R. Gächter and B. Wehrli, 1996. Nitrous oxide emissions to the atmosphere from an artificially oxygenated lake. Limnol. Ocenogr. 41:548-553.

Mengis, M., R. Gächter and B. Wehrli, 1997. Stickstoff-Elimination in Schweizer Seen. Gas, Wasser, Abwasser 77:174-180.

Niessen, F. and M. Sturm, 1987. Die Sedimente des Baldeggersees (Schweiz) - Ablagerungsraum und Eutrophierungsentwicklung während der letzten 100 Jahre. Arch. Hydrobiol. 108: $365-383$

Nipkow, F., 1927. Über das Verhalten der Skelette planktischer Kieselalgen im geschichtlichen Tiefenschlamm des Zürich- und Baldeggersees. PhD. thesis, ETH, Zürich.

Schaller, T. and B. Wehrli, 1997. Geochemical focusing of manganese in lake sediments - an indicator of deep-water oxygen. Aquatic Geochem. 2:359-378.

Schaller, T., H. C. Moor and B. Wehrli, 1997 a. Reconstructing the iron cycle from the horizontal distribution of metals in the sediment of Baldeggersee. Aquatic Sciences 59:326-344.

Schaller, T., H. C. Moor and B. Wehrli, 1997 b. Sedimentary profiles of Fe, Mn, V, Cr, As and Mo recording signals of changing deep water oxygen conditions in Baldeggersee. Aquatic Sciences 59:345-361.

Stadelmann, P., 1984. Die Zustandsentwicklung des Baldeggersees (1900-1980) und die Auswirkung von seeinternen Massnahmen. Wasser, Energie, Luft 76:85-95.

Stadelmann, P., P. Herzog, P. Arnold, J. C. Bernegger, E. Butscher, F. Hirsiger and P. Koller, 1993. Sanierung des Baldegger- und Hallwilersees und deren Einzugsgebiete. Situationsanalyse und Rechenschaftsbericht zuhanden des Gemeindeverbandes Baldegger- und Hallwilersee. Amt für Umweltschutz, Luzern.

Stadelmann, P., H. R. Bürig and E. Butscher, 1997. Massnahmen zur Seesanierung. Beispiel Baldeggersee. Gas, Wasser, Abwasser 77:16-33.

Svensson, J. M. and L. Leonardson, 1996. Effects of bioturbation by tube-dwelling chironomid larvae on oxygen uptake and denitrification in eutrophic lake sediments. Freshwater Biology $35: 298-300$.

Teranes, J., 1997. Climatic significance and geobiochemical controls on stable isotope values in Holocene lacustrine sequences: A case study from Baldeggersee, Switzerland. Ph.D. thesis ETH, Zürich.

Thomson, J., N. C. Higgs, I. W. Croudace, S. Colley and D. J. Hydes, 1993. Redox zonation of elements at an oxic/post-oxic boundary in deep-sea sediments. Geochim. Cosmochim. Acta 57:579-595.

Wehrli, B., A. F. Lotter, T. Schaller and M. Sturm, 1997. Kalibration von Klima-Proxydaten in rezenten Seesedimenten. vdf, Zürich in press.

Wehrli, B. and A. Wüest (editors), 1996. Zehn Jahre Seebelüftung: Erfahrungen und Optionen. Schriftenreihe der EAWAG Nr. 9.

Wüest, A., W. Aeschbach-Haertig, H. Baur, M. Hofer, R. Kipfer and M. Schurter, 1992a. Density structure and tritium-helium age of deep hypolimnetic water in the northern basin of Lake Lugano. Aquatic Sciences 54:205-218.

Wüest, A., N. H. Brooks and D. M. Imboden, 1992 b. Bubble plume modeling for lake restoration. Water Resources Res. 28:3235-3250.

Zolitschka, B., 1990. Spätquartäre jahreszeitlich geschichtete Seesedimente ausgewählter Eifelmaare. Paläolimnologische Untersuchungen zur spät- und postglazialen Klima- und Besiedlungsgeschichte. Documenta Naturae 60:1-226.

Züllig, H., 1982. Untersuchungen über die Stratigraphie von Carotinoiden im geschichteten Sediment von 10 Schweizer Seen zur Erkundung früherer Plankton-Entfaltungen. Schweiz. Z. Hydrologie 44:1-98.

Received 8 January 1997;

revised manuscript accepted 27 August 1997. 